\title{
Which Period Should Be Chosen for Minimal Invasive Repair of Pectus Carinatum in Terms of Complications?
}

\section{Komplikasyonlar Açısından Minimal İnvaziv Onarım Pektus Karinatum İçin Hangi Dönem Seçilmeli?}

\author{
Murat AKKUŞ 1 (D) , Tuba APAYDIN ${ }^{1}$ (D) \\ ${ }^{1}$ Department of Thoracic Surgery, Saglik Bilimleri University, Mehmet Akif Ersoy Thoracic and Cardiovascular Surgery Training \\ and Research Hospital, İstanbul, TURKEY
}

\section{Abstract}

Background: Pectus carinatum (PC) presents with anterior protrusion of the chest wall in the childhood period and becomes more prominent during puberty. Optimum time for surgery concerns the life period with flexibility of the chest wall. However, today Abramson operation is performed for younger and adult patients by many surgeons. In this study, we aimed to compare the complication results of Abramson surgery for PC between pediatric, adolescent and adult groups, to indicate the optimal appropriate period for this surgery.

Materials and Methods: From 2012 to 2018, 178 cases had symmetric-asymmetric PC identified. A total of 63 patients who could not use or had unsuccessful outcomes with a brace therapy were treated with Abramson surgery in our clinic. We classified patients into three groups: Pediatric (patients younger than 12 years), adolescent (patients between 13 and 16 years); and adult (patients between 17 and 20 years). We evaluated patients' demographics, and compared results of surgery, duration of hospitalization and complication rates.

Results: Fifty patients were male and 13 were female. The age range was 8 to 20 years (mean $14.5 \pm 2.5$ years). Symptomatic patients and chest pain in the preoperative period were seen more frequently in patients with older age, but this was not statistically significant ( $p: 0.061, p: 0.901, p: 510)$. There was no significant difference between groups with respect to duration of operation, and duration of follow up ( $p: 0.338, p: 0.646, p: 0.668$ ). In the early 30-day postoperative period, no mortality was observed. In logistic regression analysis, postoperative complications increased in patients older than 17 years, but this wasn't statistically significant ( $\mathrm{p}: 0.256)$.

Conclusions: The Abramson procedure is an effective and successful method with low complication rates in the group who do not benefit from a brace for treatment of pectus carinatum. However, complication rates may increase in the adult period, though this was not statistically significant.

Key Words: Pectus carinatum, Abramson procedure, Minimally invasive repair pectus carinatum

Öz.

Amaç: Pektus karinatum (PK) çocukluk döneminde göğüsün öne çıkması ile belirir ve ergenlik döneminde daha da ilerleyebilir. Cerrahi için en uygun zaman göğüs duvarının elastik olduğu dönemdir. Bununla beraber, bugün Abramson operasyonu çocuklar ve erişkinlerde de uygulanmaktadır. Bu çalışmada, PK için çocukluk, ergenlik ve erişkin gruplar arasında Abramson operasyonun komplikasyonları açısından en uygun dönemini karşılaştırmak amaçlandı.

Materyal ve Metod: 2012 ile 2018 yılları arasında simetrik ve asimetrik PK 178 olgu tespit edildi. Kliniğimizde brace tedavisini kullanamayan veya başarısız olan 63 olgu Abramson cerrahisi ile tedavi edildi. Olgular 3 gruba ayrıldı: Çocukluk (12 yaşından küçük olgular), ergenlik ((13-16 yaş arasında olgular) ve erişkin (17 ve 20 yaş arasında olgular) olarak sınıflandırıldı. Hastaların demografik yapıları, cerrahi sonuçları, yatış süreleri ve komplikasyon oranları değerlendirildi.

Bulgular: Elli hasta erkek, 13 hasta kadındı. Hastaların yaş aralığı 8-20 (ortanca değer $14.5 \pm 2.5$ yıl) arasında idi. Semptomatik hastalar ve göğüs ağrısı en sık olarak ileri yaş grubunda görüldü, fakat istatistiki olarak anlamlı değildi (p:0.061, p:0.901, p:510). Gruplar arasında operasyon süreleri ve takip süreleri arasında anlamlı fark izlenmedi (p: 0,338, p: 0,646, p: 0,668). Postoperatif erken 30 günlük dönemde ölüm izlenmedi. Lojistik regresyon analizinde postopertaif komplikasyonların 17 yaş üstü grupta arttığı saptandı ancak istatistiki olarak anlamlı izlenmedi ( $p: 0.256)$.

Sonuç: Abramson tekniği brace tedavisinden fayda görmeyen PK tedavisinde düşük komplikasyon oranları ile etkin ve başarılı yöntemdir. Komplikasyon oranı erişkin periodda istatistiksel olarak anlamlı olmasa da artabilir.

Anahtar kelimeler: Pektus karinatum, Abramson operasyonu, Minimal invazin onarım pektus karinatum
Sorumlu Yazar / Corresponding Author

Murat Akkuş, MD

Department of Thoracic Surgery, Saglik Bilimleri University, Mehmet Akif Ersoy Thoracic and Cardiovascular Surgery Training and Research Hospital, Istasyon Mahallesi Turgut Ozal Bulvari No:11, Halkali-Kucukcekmece,Istanbul, 34303, TURKEY.

E-mail: akkusmdr@gmail.com

Geliş tarihi / Received: 19.06.2020

Kabul tarihi / Accepted: 01.03.2021

DOI: 10.35440/hutfd.754903 


\section{Introduction}

Pectus carinatum (PC) presents with anterior protrusion of the chest wall in the childhood period and becomes more prominent during puberty (1). It is classified as chondrogladiolar and chondromanubrial subtypes according to the anatomical position of the highest protrusion. The Nuss procedure was a successful treatment modality for pectus excavatum as a minimally invasive technique in recent years (2). Abramson described a minimally invasive technique with the technique of Nuss procedure, where a bar is placed over the sternum to give the convenient shape to the chest wall (3). The bar is held over the sternum with the help of wires. Optimum range period is reported as between 12 and 18 years because of the flexibility of the chest wall (4). However; today, this operation is performed for younger and adult patients by many surgeons (5).

In this study, we compared the complication results of Abramson surgery for PC between pediatric, adolescent and adult groups, to indicate the optimal appropriate period for this surgery.

\section{Materials and Methods}

From 2012 to 2018, symmetric-asymmetric PC was identified in 178 cases. All cases initially had orthotic brace treatment; however, 63 patients who could not use the brace or had unsuccessful results were treated with Abramson surgery in our clinic. We classified patients into three groups: Pediatric (patients younger than 12 years), adolescent (patients between 13 and 16 years); and adult (patients between 17 and 20 years). We evaluated patients' demographics, and compared results of surgery, duration of hospitalization and complication rates. Written consent was obtained from all patients or from their parents. Approval was obtained from the local ethical committee of our institution (date of approval: 08.06.2018, approval no: 2018/22).

Posteroanterior and lateral chest $X$-rays, routine blood tests, electrocardiogram, thoracic computed tomography, and pulmonary function tests were obtained for all cases in the preoperative period. A compression test was performed to evaluate the flexibility of the chest wall, by compressing the sternum while the patient was standing against the wall. Cosmetic reasons were the indication for surgery in most cases.

Fifty patients were male and 13 were female. Age range was 8 to 20 years (mean $14.5 \pm 2.5$ years).

Three age groups were generated. The pediatric group was composed of 21 patients between 8 and 12 years (mean $11.8 \pm 1.6$ years). The adolescent group composed of 20 patients between 13 and 16 years (mean $14.6 \pm 0.5$ years). The adult group comprised 22 patients between 17 and 20 years (mean $17 \pm 1.4$ years). Ratio of males to females was $1.6(13 / 8)$ in the pediatric group, $5.6(17 / 3)$ in adolescent group, and $10(20 / 2)$ in the adult group.
Preoperative clinical data for patient groups is shown in Table 1. Surgery was performed with general anesthesia and the Abramson technique as described by Abramson in 2005 (3).

\section{Surgical Procedure}

The patient is intubated with single lumen tube under general anesthesia. Both arms are abducted to 90 degrees in supine position. The highest protruded point of the chest wall is depressed manually and the proper size and shape of the bar is defined. The template with the proper size is shaped according to the chest wall. Pectus bar (Hipokrat $^{\circledR}$, İzmir, Turkey) with the same length as the template is bent similar to the template. Then $3 \mathrm{~cm}$ skin incisions are made on midaxillary lines on bilateral sides and a tunnel is formed in the subpectoral area over the line of the highest protruded point of the chest wall. Two costas are deperiosted on bilateral sides and 2 sternal cables with an aspiration catheter attached to the tip (Pioneer ${ }^{\circledR}$ Surgical, MI, ABD) are passed under the ribs to stabilize the fixators. Catheters are drawn back and fixators are stabilized on bilateral sides with these steel cables. The bar is passed through the subpectoral tunnel and the tips of the bars are placed in the stabilizers. Bars are stabilized in the fixators with pins and cables.

Patients were followed at 1, 3, 6, 12 and 24 months after the first operation and 1 and 12 months after removal of the bars.

\section{Statistical Analyses}

Statistical analysis was completed using IBM SPSS Statistics for Windows, Version 23.0 (IBM Corp., Armonk, NY). Pearson chi-square test was performed for categorical variables. The normality assumption was checked with the Shapiro-Wilk test. The Kruskal Wallis test was used for comparison of non-parametric variables between groups and Bonferroni-Dunn test was used as a post-hoc test for significant cases. Binary logistic regression analysis was used to determine the effect of the study groups on postoperative complications. Data are expressed as $n$ (\%) or mean \pm SD (range), as appropriate. $P$ values $<0.05$ were considered statistically significant.

\section{Results}

Symptomatic patients and chest pain in the preoperative period were seen more frequently in patients with older age, but this was not statistically significant ( $p: 0.061$, p:0.901, p:510) (Table 1). There was no significant difference between groups with respect to duration of operation and duration of follow up (p:0.338, p:0.646, p:0.668). In the early 30 -day postoperative period, no mortality was observed. The most frequent postoperative complications were observed in the adult group (45.5\%), followed by adolescent group (30\%) and pediatric group (28.6\%); however, these were not statistically significant (Table 2) (p:0.436). 
Table 1. Preoperative and peroperative clinical data of the patients

\begin{tabular}{|c|c|c|c|c|c|}
\hline & Total (n:63) & Pediatric Group (n:21) & Adolescant Group (n:20) & Adult Group (n:22) & $p$ \\
\hline Age & $14,5 \pm 2,5(820)$ & $11,8 \pm 1,6(8-12)$ & $14,6 \pm 0,5(13-16)$ & $17 \pm 1,4(17-20)$ & $<0,001$ \\
\hline \multicolumn{6}{|l|}{ Sex } \\
\hline Female & $13(20,6 \%)$ & $8(38,1)$ & $3(15 \%)$ & $2(9,1)$ & 0,061 \\
\hline Male & $50(79,4 \%)$ & $13(61,9)$ & $17(85 \%)$ & $20(90,9)$ & \\
\hline Symptoms & $77(55 \%)$ & $3(14,3)$ & $42(63,6 \%)$ & $4(18,2)$ & 0,901 \\
\hline Dyspnea & $1(1,6 \%)$ & $0(0)$ & $1(5 \%)$ & $0(0)$ & 0,317 \\
\hline Chest pain & $8(12,7 \%)$ & $3(14,3)$ & $1(5 \%)$ & $4(18,2)$ & 0,510 \\
\hline $\begin{array}{l}\text { Duration of hospitalisation } \\
\text { (day) }\end{array}$ & $4,6 \pm 2,3(3-13)$ & $4,1 \pm 1,8(3-10)$ & $4,9 \pm 2,4(3-13)$ & $\begin{array}{l}4,7 \pm 2,6 \\
(3-13) \\
\end{array}$ & 0,646 \\
\hline Duration of follow-up (months) & $35,6 \pm 9,7(10-58)$ & $\begin{array}{l}37,1 \pm 6,5 \\
(25-50) \\
\end{array}$ & $\begin{array}{l}35,7 \pm 8,2 \\
(24-49)\end{array}$ & $\begin{array}{l}34 \pm 13,1 \\
(10-58)\end{array}$ & 0,668 \\
\hline Duration of Surgery (minutes) & $72,2 \pm 26(45-150)$ & $72,4 \pm 21,9(60-150)$ & $77,5 \pm 34,6(50-150)$ & $67,1 \pm 20(45-120)$ & 0,338 \\
\hline
\end{tabular}

Data are presented as $\mathrm{n}(\%)$ or mean \pm SD (range). Pearson chi-square test, Kruskall-Wallis test. $\mathrm{n}$ :Number of patients

Table 2. Postoperative complications of patient groups

\begin{tabular}{|l|l|l|l|l|}
\hline & $\begin{array}{l}\text { Total } \\
(\mathbf{n : 6 3 )}\end{array}$ & Pediatric Group (n:21) & Adolescant Group (n:20) & $\begin{array}{l}\text { Adult } \\
\text { Group (n:22) }\end{array}$ \\
\hline Complications (total) & $22(34,9 \%)$ & $6(28,6 \%)$ & $6(30 \%)$ & $10(45,5 \%)$ \\
\hline Sliding of bar & $5(7,9 \%)$ & $1(4,8 \%)$ & 0 & $4(18,2 \%)$ \\
\hline Bar allergy & $5(7,9 \%)$ & $1(4,8 \%)$ & $2(10 \%)$ & 0,436 \\
\hline Bar intolerance & $3(4,8 \%)$ & $2(9,5 \%)$ & 0 & 0,538 \\
\hline Splitting of wires & $5(7,9 \%)$ & 0 & $1(5 \%)$ & $1(4,5 \%)$ \\
\hline Costa fracture & $2(3,2 \%)$ & $1(4,8 \%)$ & 0,862 & $4(18,2 \%)$ \\
\hline Pneumothorax & $3(4,8 \%)$ & $1(4,8 \%)$ & $1(5 \%)$ & 0,529 \\
\hline Recurrence & $2(2 \%)$ & 0 & $1(5 \%)$ & 0,095 \\
\hline
\end{tabular}

Data are presented as $\mathrm{n}(\%)$. Pearson chi-square test. $\mathrm{n}$ :Number of patients

In the adolescent and adult groups, one case each had recurrence observed. In logistic regression analysis, postoperative complications increased in patients older than 17 years, but this wasn't statistically significant ( $p: 0.256)$ (Table 3 ). In 1 case in the adult group, the bar was removed at 23 months due to allergy, but recurrence was not observed in the follow-up with this case. No case had the overcorrection complication observed.

Table 3. Logistic regression analysis for postoperative complications.

\begin{tabular}{lll}
\hline GRUP & OR $(\mathbf{9 5 \%} \mathbf{C l})$ & P \\
\hline Pediatric group & Reference & - \\
Adolescant group & $1,071(0,279-4,115)$ & 0,920 \\
Adult group & $2,083(0,588-7,383)$ & $\mathbf{0 , 2 5 6}$ \\
\hline
\end{tabular}

\section{Discussion}

PC reconstruction was described classically by Ravitch (6). The Ravitch operation involves a midsternal operation incision, elevation of the bilateral pectoral muscles, resection of the subperichondral defective costal cartilage and transverse sternal osteotomy. The minimally invasive repair of pectus carinatum (MIRPC) described by Abramson in 2005 involves shorter operation duration, less blood loss, less pain, shorter hospital stay and is esthetic so it is applied more commonly (3). Later, wearing a compression brace was developed as noninvasive method and became the primary choice for PC $(7,8)$. Additionally, success of brace treatment is associated with patient compli- ance, chest flexibility capacity and period of life (9). Patient compliance may be a problem for children at young ages, while results may not be obtained in the adolescent and adult group due to reasons such as shame about appearance under clothing and discomfort (10). As a result, MIRPC still continues to be a chosen method.

MIRPC operations are easily tolerated by patients. Our series was found to be compatible with the literature for operation and admission durations (11). One case each in the adolescent and adult groups had partial recurrence identified after bar removal. When these cases were retrospectively assessed, insufficient operative correction was observed and both cases achieved satisfactory results with added brace treatment.

In terms of complications, the postoperative pneumothorax rate of $4.8 \%$ appears compatible with the literature and there were no significant differences between the groups in terms of early period complications (12). All pneumothorax cases healed with conservative treatment. Again, there appeared to be no statistical differences between the groups in terms of early and late period complications like bar allergy and costa fracture. Bar allergy rates $(7.9 \%)$ were not observed to be different from the literature (13).

Additionally, though not statistically significant, late period complications like splitting of wires and bar sliding were observed to be higher in the adult group. The late period complications in the adult group may be explained by the higher chest rigidity compared to other groups. 
Logistic analysis observed total complications were higher in the adult group compared to the pediatric and adolescent groups, though this was no statistically significant.

Before the operation, the patient's chest wall is pushed to compress the chest protrusion into place and check the flexibility in all patients. Those with flexible chests are taken for Abramson operation. This test measurement observed the adult group had flexible chests, though they were more rigid than in the other groups. Cases without flexibility are taken for the Ravitch operation. Chest stiffness may cause separation of the bar from the wires fixing it to the costa due to increased load. Due to the new shape and mobility of the chest, the bar may slide and protrude from the skin. These cases were corrected with reoperation.

Some cases without compliance to brace treatment or not obtaining results do not want to accept or wish to delay the Abramson operation due to fear and anxiety of the patient or their family. In adult periods, the same patients may apply for operation due to esthetic worries.

The period most suitable for the operation is controversial. Abramson stated that the most appropriate age for the MIRPC operation was the pubertal period due to rapid growth (12). Yüksel et al. recommended the 12-18-year age interval due to appropriate flexibility of the chest (4). Additionally, Suh et al. performed MIRPC in a group with high chest stiffness and mean age of 24 years and stated that it may be performed at all ages $(14,15)$. In our series, the complication rate in the adult group was higher, though not statistically significant, so it is thought to be more appropriate to perform the procedure before this period.

Limitations of the study include the low patient number, single center results, and lack of long-term follow up after bar removal.

\section{Conclusion}

MIRPC is an effective and successful method with low complication rates for PC patients without benefit from brace treatment. However, though not statistically significant, complication rates may increase in the adult period compared to the pediatric and adolescent periods.

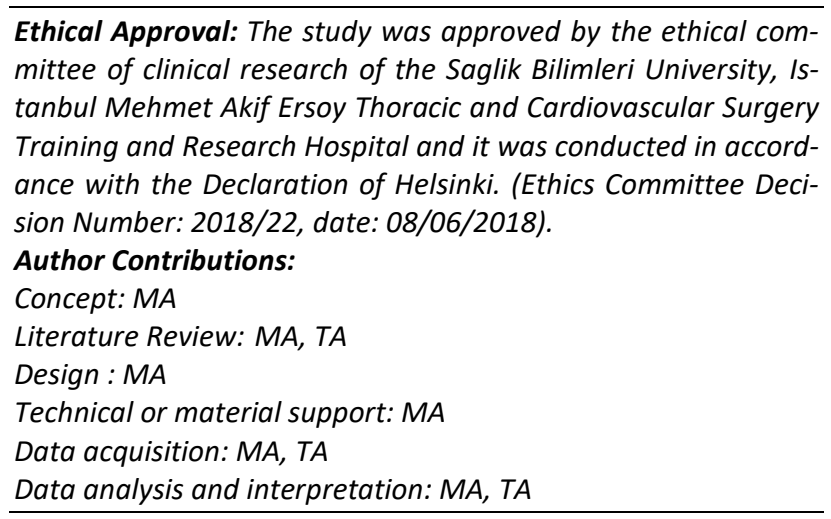

Writing manuscript: MA, TA

Critical revision of manuscript: $M A$

Conflict of Interest: Authors declared no conflict of interest. Financial Disclosure: Authors declared no financial support

\section{References}

1. Özkaya M, Bilgin M. Minimally invasive repair of pectus carinatum by modification of the Abramson technique. Wideochir Inne Tech Maloinwazyjne. 2018;13(3):383-387. doi:10.5114/wiitm.2018.75888.

2. Nuss D, Kelly Jr RE, Croitoru DP, Katz ME. A 10-year review of a minimally invasive technique for the correction of pectus excavatum. Journal of pediatric surgery. 1998;33(4):545-52.

3. Abramson H. A minimally invasive technique to repair pectus carinatum. Preliminary report. Archivos de Bronconeumología ((English Edition)). 2005;41(6):349-51.Doi: 10.1016/s1579-2129(06)60235-8.

4. Yuksel M, Lacin T, Ermerak NO, Sirzai EY, Sayan B. Minimally invasive repair of pectus carinatum. The Annals of thoracic surgery. 2018;105(3):915-23. Doi: 10.1016/j.athoracsur.2017.10.003.

5. Bilgin $M$, Oral A. Early results of minimal invasive surgery in patients with pectus carinatum. Turk Gogus Kalp Damar 2012;20:307-311. doi 10.5606/tgkdc.dergisi.2012.058.

6. Ravitch MM. Operative correction of pectus carinatum (pigeon breast). Annals of surgery. 1960;151(5):705.

7. Kravarusic D, Dicken BJ, Dewar R, Harder J, Poncet P, Schneider M, Sigalet DL. The Calgary protocol for bracing of pectus carinatum: a preliminary report. Journal of pediatric surgery. 2006;41(5):923-6.

8. Martinez-Ferro M, Fraire $C$, Bernard S. Dynamic compression system for the correction of pectus carinatum. InSeminars in pediatric surgery 2008 Aug 1 (Vol. 17, No. 3, pp. 194-200). WB Saunders. Doi: 10.1016/j.athoracsur.2016.12.019.

9. Cohee AS, Lin JR, Frantz FW, Kelly Jr RE. Staged management of pectus carinatum. Journal of pediatric surgery. 2013;48(2):315-20.

10. Lee RT, Moorman S, Schneider M, Sigalet DL. Bracing is an effective therapy for pectus carinatum: interim results. Journal of pediatric surgery. 2013;48(1):184-90.

11. Yüksel $M$, Bostanci $K$, Evman $S$. Minimally invasive repair of pectus carinatum using a newly designed bar and stabilizer: a single-institution experience. European journal of cardio-thoracic surgery. 2011;40(2):339-42.

12. Abramson H, D'Agostino J, Wuscovi S (2009) A 5-year experience with a minimally invasive technique for pectus carinatum repair. J Pediatr Surg. 44(1):118-123.

13. Abramson $\mathrm{H}$, Aragone $\mathrm{X}$, Blanco JB, Ciano A, Abramson L. Minimally invasive repair of pectus carinatum and how to deal with complications. J Vis Surg. 2016;2:64.

14. Suh J, Joo S, Lee GD, Haam SJ, Lee S. Minimally Invasive Repair of Pectus Carinatum in Patients Unsuited to Bracing Therapy. Korean J Thorac Cardiovasc Surg 2016;49:92-98.

15. Katrancioglu Ö, Akkas Y, Karadayi S, Sahin E, Kaptanoğlu $M$. Is the Abramson technique effective in pectus carinatum repair? Asian Journal of Surgery, 2018;41:1,7376,ISSN 1015-9584. 